\title{
Effects of Brace Configuration and Structure Height on Seismic Performance of BRBFs Based on the Collapse Fragility Analysis
}

\author{
Jong Wan Hư ${ }^{1,2}$, Hamed Rahman Shokrgozar ${ }^{3 *}$, Edris Salehi Golsefidiª , Iman Mansouri5,6 \\ 1 Department of Civil and Environmental Engineering, Incheon National University, Incheon 22012, South Korea \\ 2 Incheon Disaster Prevention Research Center, Incheon National University, Incheon, 22012, South Korea \\ ${ }^{3}$ Faculty of Technical and Engineering, University of Mohaghegh Ardabili, Daneshgah Street, Ardabil, 56199-11367, Iran \\ ${ }^{4}$ Faculty of Civil Engineering, Babol Noshirvani University of Technology, Shariati Av., Babol, 47148-71167, Iran \\ ${ }^{5}$ Department of Civil Engineering, Birjand University of Technology, Birjand, 9717434765, Iran \\ ${ }^{6}$ Institute of Research and Development, Duy Tan University, Da Nang 550000, Vietnam \\ *Corresponding author, e-mail: h_rshokrgozar@uma.ac.ir
}

Received: 28 October 2018, Accepted: 02 July 2020, Published online: 12 August 2020

\begin{abstract}
The brace configuration and structure height are two factors that have a significant effect on the seismic behavior of braced frame buildings. In the present study, the buckling-restrained braced (BRB) frames were considered to estimate the effect of these two parameters using probabilistic seismic assessment methods. The uncertainty in the different parameters involved in the seismic design of the structural system was also considered. Four, six, and ten-story buildings with the Chevron and inverted Chevron bracing configurations were designed, and their responses due to various ground motions were estimated using incremental nonlinear dynamic analyses. Fragility curves, mean annual frequency of exceeding immediate occupancy (IO), and collapse prevention (CP) states were generated using probabilistic seismic analysis, fragility curves concept, and drift hazard curves. The results demonstrate that the inverted Chevron type BRBFs has better structural performance than Chevron bracing types. Furthermore, an increase of the height of structures, despite lower drift's hazards, increases the fragility probability.
\end{abstract}

Keywords

bracing configuration, height of structure, mean annual frequency, seismic demand hazard, Buckling Restrained Braces

\section{Introduction}

Braces, an essential structural element to resist lateral seismic forces, are widely used in various types of buildings. While most engineers have increasingly turned to concentrically braced steel frames as a seismic resistance system, braces in this system have been observed to have some disadvantages, such as connection and member fracture, severe loss of strength and stiffness at compression and cyclic loads, un-symmetric behavior in tension and compression, and low capacity to dissipate energy [1-4]. In recent years, "Buckling-restrained braces" (BRBs), a new generation of braces, have been reported not to have the unfavorable behavior characteristics of the conventional braces. BRBs are classified as the energy-dissipation devices that can be quickly replaced after a severe earthquake [5-7]. The buckling restrained brace generally consists of a core plate covered with a restraining part to prevent buckling [8,9]. An un-bonded material or a clearance is provided between the core plate and the restraining part so that the axial force borne by the core plate is not transmitted to the restraining part (see Fig. 1).

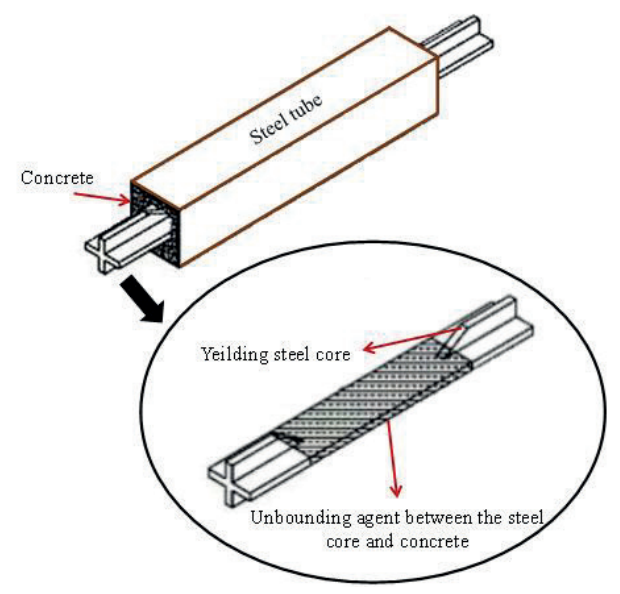

Fig. 1 The component of BRB [12] 
The steel core member is designed to resist the axial forces with a full tension or compression yield capacity without the local or global flexural buckling failure [10]. The principal advantage of BRBs is their ability to yield in both compression and tension. Therefore, BRBs exhibit symmetric hysteretic behavior (see Fig. 2) that is more stable than a typical buckling [11].

Several previous studies have compared the seismic performance of BRBFs. For instance, Asgarian and Shokrgozar [13] determined the seismic response modification factor of BRBF using incremental dynamic analysis and pushover analysis. The seismic reliability of buckling restrained frames eccentrically braced frames, and moment-resisting frames in both near field and far fault cases was calculated by Lin et al. [14]. Güneyisi [15] determined the seismic reliability of retrofitted moment resisting frames using the buckling restrained braced frames. Likewise, Ariyaratana and Fahnestock [16] investigated the structural performance of buckling-restrained braces and moment frame-buckling restrained brace system, which is a dual one, based on the results of the incremental dynamic analysis. Based on that, it has been specified that save resistance has been an important factor in the seismic behavior of this bracing system. In addition,

\section{Conventional braces}

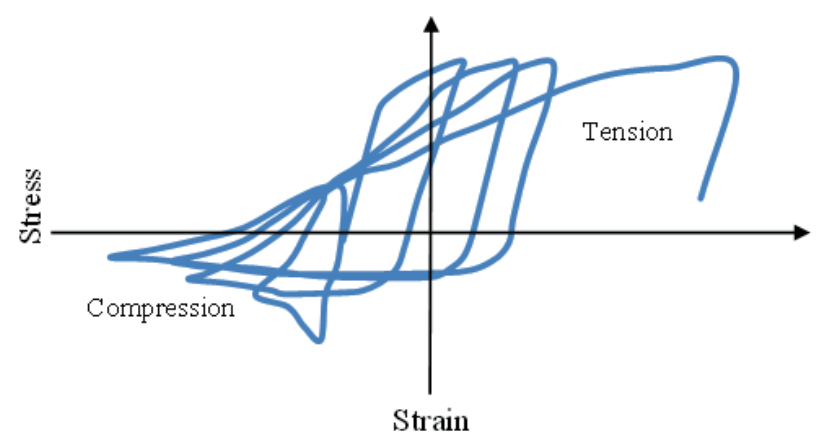

Core loaded braces

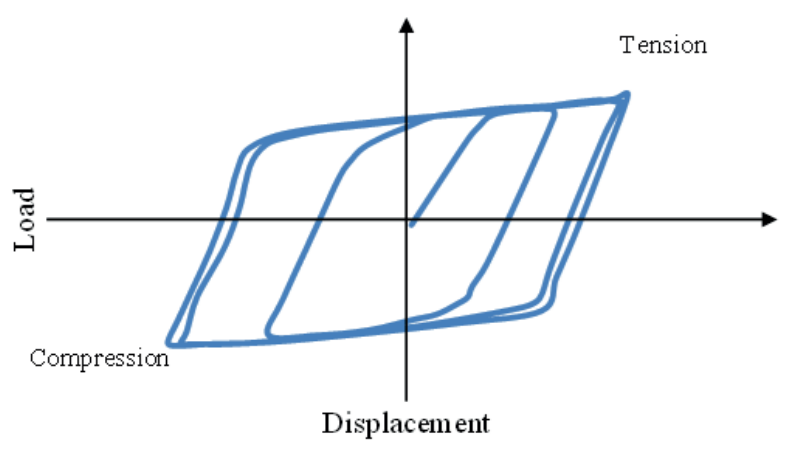

Fig. 2 Distinct behaviors of BRB and conventional brace [11]
Maley et al. [17] suggested the design method based on displacement for moment frame-buckling restrained brace systems. The results of this study demonstrated that the proposed method provides a suitable control of displacement and relative displacement of the structure.

Furthermore, Sutcu et al. [18] investigated the performance of buckling-restrained braces attached to a steel frame to retrofitting concrete buildings. The results showed that relative displacements of stores were partly decreased in retrofitted concrete buildings with a buckling-restrained brace as compared to the retrofitted primary building with the common braces. The seismic behavior of an innovative BRB called hybrid buckling restrained brace (HBRB) was also investigated by Atlayan and Charney [19]. The authors used steel material with various properties for each segment of HBRB. The results demonstrated that, as compared to the prevailing $\mathrm{BRB}, \mathrm{BRBs}$ behavior amended, especially in the reduction of residual displacement. Similarly, Hu and Choi [20] proposed a methodology that combines recentering systems using superelastic shape memory alloys into BRBs. Finally, Jiang et al. [21] studied the impact of stiffness and strength of the exterior supported segment, core length, and other geometric parameters on BRB performance using modified finite-element methods.

Merczel et al. [2] were studied the weak story behavior and the collapse of diagonally concentrically braced frames. They primary purpose to develop an effect on an effective design procedure for considering this effect at Eurocode 8 provisions. Merczel et. al [1] studied the causes of weak story mechanisms in concentrically braced frames subjected to seismic action. They described the relation of the weak story development at the diagonally braced frames with the plastic deformation, and finally introduce a redesign method to prevent the weak story happening at this seismic resistance system.

AISC 341-2010 code specifies the use of diagonal, single- $\mathrm{V}$, inverted- $\mathrm{V}$, split- $\mathrm{X}$ to be used in the case of BRBFs. However, while the code enables the selection of a proper brace configuration for BRBFs, it does not distinguish their performance. The values of response reduction factor, overstrength factor, and ductility for all brace configurations are kept the same in the present international code, although their response to earthquakes can vary considerably.

Seismic risk analysis is the main step towards reducing the social and economic losses caused by earthquakes [22-24]. The present study focuses on the evaluation of the seismic response of low-to high-rise BRBF 
systems with different brace configurations and structural height. The present study aims to investigate the effect of these two parameters on the seismic behavior of low and mid-rise buildings. To this end, the incremental dynamic analyses are used for the estimation of the response of the mentioned models from the elastic range to the final global dynamic instability (collapse). Two methods are applied to evaluate the mean annual frequency of exceeding two limit states. This parameter is estimated using both solutions "based on displacement" in the demand and capacity factor design (DCFD) method and the probabilistic seismic demand analysis (fragility curves) method.

\section{Probabilistic seismic analysis}

\subsection{Demand and capacity factor design (DCFD)}

Seismic probabilistic risk assessment aims to determine the probability distribution of the frequency of adverse consequences due to the potential effects of the earthquake $[25,26]$. The probabilistic analysis of seismic demand is a method to estimate the mean annual frequency of the exceeding limit state and hazard demand. Mean annual frequency of exceeding a limit state $\left(\lambda_{L S}\right)$ has been defined as a product of the annual mean ratio of events occurrence with major seismic intensity (v) than a specified minimum level in $[D>C]$, demand exceeding probability of capacity, [27], hence (see Eq. (1)) :

$\lambda_{L S}=v \cdot P[D>C]$.

The mean annual frequency of exceeding a limit state is determined by splitting Eq. (1) into seismic activity and structural parts. In the probabilistic seismic demand analysis method proposed by Vamvatsikos and Cornell [28], the mean annual frequency of exceeding a limit state is computed as follows (see Eq. (2)):

$$
\lambda_{L S}=\int_{I M=0}^{I M=\infty} F_{C, I M}(x) \cdot d \lambda_{I M}
$$

where $d \lambda_{I M}$ and $F_{C, I M}$ are the differential of the intensity measure, and the fragility curve is corresponding to various relative displacements, respectively. The intensity measure in this study is considered the spectral acceleration in the first period with $5 \%$ damping, and the spectral acceleration hazard was computed using the power-law relationship, as suggested by Luco and Cornell [29] (see Eq. (3)):

$$
\lambda_{I M}=k_{0}(I M)^{-k}
$$

Where $k_{0}$ and $k$ are seismic parameters estimated from the seismic hazard analysis of the studied zone. To estimate the annual frequency of exceeding a limit state, the capacity and demand random variables have been assumed to be statistically independent with the log-normal statistical distribution. Therefore, Eq. (1) was revised according to the mentioned assumption, and the total rule of possibilities was computed as follows (see Eq. (4)).

$\lambda_{L S}=v \cdot \sum_{\text {all d all } x} \sum_{P}[D>C \mid D=d] \cdot P\left[D=d \mid S_{a}=x\right] \cdot P\left[S_{a}=x\right]$,

where $v$ is the mean rate of occurrence of events with seismic intensity larger than a certain minimum level; $P[D>C \mid D=d]$ is the conditional probability that the limit state variable, $D$ exceeds the capacity variable for a given value of capacity. Two sources of uncertainties, "aleatory uncertainty" (due to inherent randomness) and "epistemic uncertainty" (due to limited knowledge) were considered in demand, capacity, and spectral acceleration hazard. Therefore, the annual frequency of exceeding limit states from the immediate occupancy and the onset of collapse were calculated as follows (see Eq. (5)) [27]:

$\lambda_{L S}=k_{0}\left(S_{a}^{\eta_{c}}\right)^{-k} \times e^{\frac{1}{2} \beta_{U H}^{2}} \times e^{\frac{1}{2} \frac{k^{2}}{b^{2}}\left(\beta_{R D}^{2}+\beta_{U D}^{2}\right)} \times e^{\frac{1}{2} \frac{k^{2}}{b^{2}}\left(\beta_{R C}^{2}+\beta_{U C}^{2}\right)}$,

where $S_{a}^{\eta_{c}}$ is spectral acceleration corresponding to the amount of relative displacement $\left(\eta_{c}\right)$ and equal to $\left(\eta_{c} / a\right)^{1 / b}$. $\beta_{R D}, \beta_{U D}, \beta_{U C}$ and $\beta_{R C}$ are the fractional standard deviation of demand and capacity variables, indicating randomness and uncertainty, respectively. $\beta_{U H}$ is frictional standard deviation at spectral acceleration hazard.

\subsection{Probabilistic seismic demand analysis (fragility curves)}

Fragility function from the limit state was defined as follows (see Eq. (6)) [30]:

$$
F_{C, S_{a, c}}(x)=P\left[S_{a} \geq S_{a, c} \mid S_{a}=x\right]=P\left[S_{a, c} \leq x\right],
$$

where $F_{C, S_{a, c}}(x)$ is the value of the fragility curve in spectral acceleration corresponding to each limit state. Since the demand variable is statistically independent of the capacity variable, the fragility function can be expressed as a probable case $S_{a, c}$ to be less or equal to $x$. In the present study, the log-normal cumulative distribution function was used to determine the fragility function in each limit state [31]. Based on that, as shown in Eq. (7): 


$$
F_{C, S_{a, c}}(x)=\Phi\left(\frac{\ln x-\mu}{\beta}\right)
$$

where $\Phi$ is the log-normal cumulative distribution function, while $\mu$ and $\beta$ indicate are mean and standard deviation from $\ln S_{a}$ data, respectively.

\section{Modeling of study frames}

In the present study, six buildings with buckling-restrained braces system were designed. Three different heights (4-, 6- and 10-story) and two different bracing configurations (Chevron and inverted Chevron) were considered. All braces were located at the perimeter of a building (see Fig. 3). The story height was assumed to be $3.2 \mathrm{~m}$. ST-37 steel type material (with $235 \mathrm{MPa}$ yield stress) was used to design the elements. The dead and live loads of 6.5 and $2 \mathrm{kN} / \mathrm{m}^{2}$, respectively, were used for gravity load.

ASCE7-10 [32] code was also applied for the calculation of seismic loads, and the required seismic parameters are shown in Table 1. To design, the allowable stress method was used, and the braces were designed to endure the whole lateral force $(100 \%)$. The hinge connection was considered at the beam to column and braces to beam and column connections.

The computational model of the structures was developed using OpenSees software [33]. This software is finite-element software that was specifically designed in
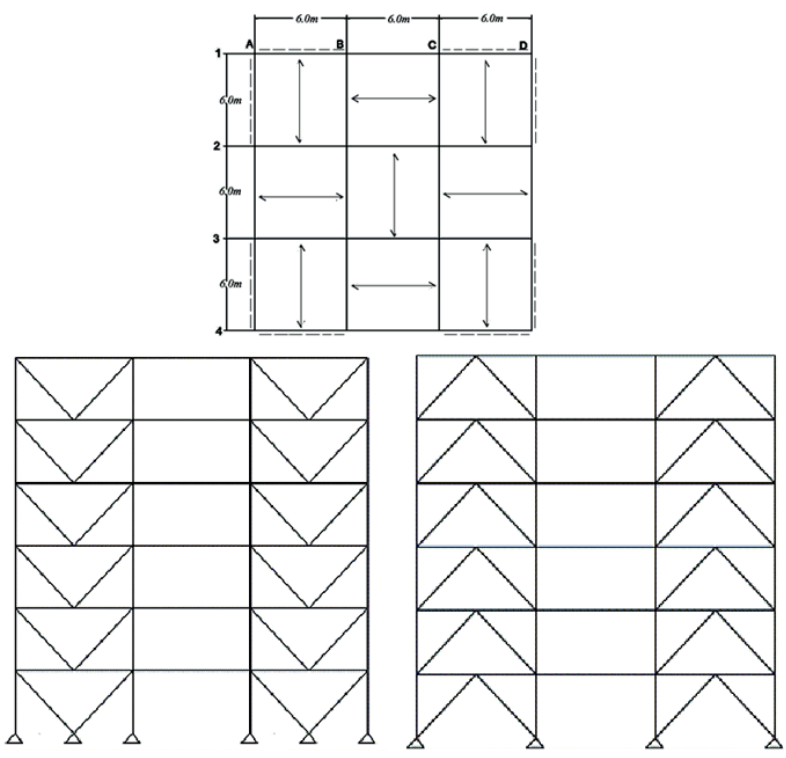

Fig. 3 Plan and bracing configurations

Table 1 Required seismic parameters in the design

\begin{tabular}{cccccccc}
\hline$N_{V}$ & $N_{a}$ & $C_{V}$ & $C_{a}$ & $R$ & $S$ & $I$ & $Z$ \\
\hline 1 & 1 & 0.56 & 0.4 & 10 & $\mathrm{SC}$ & 1 & 0.4 \\
\hline
\end{tabular}

performance systems of soil and structure under earthquake. For modeling of the members in the nonlinear range of deformation, the following assumptions were considered. All members were modeled using the beam-column element. The fiber section was considered as the section of all elements, and p-delta matrix stiffness was used for the geometric nonlinearity that is sufficiently accurate for such an application. For the dynamic analysis, story masses were placed in the story levels considering the action of the rigid diaphragm.

To predict linear or nonlinear buckling of columns, both elements' usual stiffness matrix and element geometric stiffness matrices were considered. An initial midspan imperfection of $1 / 1000$ for all columns was considered, and a fiber cross-section element was considered for plastification of the element over the member length and cross-section for the linear and nonlinear buckling prediction. To consider geometric nonlinearities, the simplified P-stiffness matrix was considered. To investigate the modeling precision, the amounts of the first natural periods of the designed structures and models, as mentioned earlier, were compared (see Table 2).

\section{Results}

\subsection{Incremental dynamic analysis}

The incremental dynamic analysis (IDA) was used to estimate the probabilistic quantities such as fragility curve [34-36], the mean annual frequency of exceeding limit states, and the hazard of relative displacement. Based on that, the behavior of the structure from the linear elastic step to the final collapse was investigated by choosing 13 accelerograms from different records of the earthquake (see Table 3 for further detail).

The intensity measured parameters (IM) were assumed to be spectral acceleration corresponding with the first mode and 5\% damping $\left(S_{a}\left(T_{1}, 5 \%\right)\right)$ and the damage measured parameters (DM) were also considered the maximum inter-story drift $\left(\theta_{\max }\right)$. The hunt and fill algorithm

Table 2 Periods corresponding with the 1st mode

\begin{tabular}{lccc}
\hline Story level & $\begin{array}{c}\text { Brace } \\
\text { configuration }\end{array}$ & $\left(T_{1}\right)_{\text {Model }}(\mathrm{sec})$ & $\left(T_{1}\right)_{\text {Design }}(\mathrm{sec})$ \\
\hline 4 & $\mathrm{~V}$ & 0.7640 & 0.7556 \\
4 & Inverted V & 0.6678 & 0.6732 \\
6 & $\mathrm{~V}$ & 1.07062 & 1.0681 \\
6 & Inverted V & 0.9697 & 0.9764 \\
10 & $\mathrm{~V}$ & 1.7397 & 1.7313 \\
10 & Inverted V & 1.5904 & 1.5740 \\
\hline
\end{tabular}


Table 3 Accelerogram database for IDA

\begin{tabular}{|c|c|c|c|c|c|c|}
\hline No & Earthquake Location & Station-(Year) & Duration (sec) & $\mathrm{R}(\mathrm{km})$ & $\mathrm{M}$ & PGA (g) \\
\hline 1 & Chi-Chi, Taiwan & TCU070-(1999) & 90 & 19.1 & 7.6 & 0.255 \\
\hline 2 & Victoria, Mexico & Cerro Prieto-(1980) & 24.45 & 34.8 & 6.1 & 0.587 \\
\hline 3 & Whittier Narrows & 116th St School LA-(1987) & 40 & 22.5 & 6 & 0.396 \\
\hline 4 & Northridge & 24605 LA-Univ. Hospita-(1994)1 & 40 & 34.6 & 6.7 & 0.493 \\
\hline 5 & Kocaeli, Turkey & Mecidiyekoy-(1999) & 44 & 62.3 & 7.4 & 0.068 \\
\hline 6 & Northridge & Lake Hughes-(1994) & 40 & 22.8 & 6.7 & 0.257 \\
\hline 7 & Northridge & Westmoreland-(1994) & 30 & 29 & 6.7 & 0.401 \\
\hline 8 & Chi-Chi, Taiwan & TCU045-(1999) & 90 & 24.06 & 7.6 & 0.512 \\
\hline 9 & Loma Prieta & Coyote Lake Dam (Downst)-(1989) & 39.95 & 22.3 & 6.9 & 0.16 \\
\hline 10 & Northridge & Beverly Hills-(1994) & 23.98 & 20.8 & 6.7 & 0.617 \\
\hline 11 & Imperial Valley & Superstition Mtn Camera-1979 & 28.28 & 26 & 6.5 & 0.195 \\
\hline 12 & N. Palm Springs & Riverside Airport-(1986) & 25 & 71.1 & 6 & 0.04 \\
\hline 13 & Morgan Hill & Corralitos-(1984) & 36 & 22.7 & 6.2 & 0.109 \\
\hline
\end{tabular}

were chosen to trace the IDA curves. Analyses were performed at the increasing levels of IM by increasing steps until numerical non-convergence was encountered. A single IDA curve was procured by scaling a given record by a scalar factor incremented in $\mathrm{n}$ steps [37,38]. An IDA curve is a collection of IDA curves of the same structural model under different ground motions that all are parameterized on the same IMs and DM [39]. The results of the mentioned analysis are summarized in Figs. 4 to 6.

According to the above IDA curves, the structures with V-shaped buckling-restrained braces demonstrated a softer behavior as compared to those with inverted Chevron braces. Therefore, against selected records, the maximum relative displacement of this kind of configuration can also be more than inverted Chevron braces.

In previous research, different performance levels have been suggested by seismic codes to evaluate the seismic behavior of structures. In the present study, we focused on two immediate occupancies (IO) and collapse prevention (CP) limit states. Based on the FEMA 350, immediate occupancy limit state was set to appear at $\theta_{\max }=2 \%$, for ground motions with a $10 \%$ chance of exceeding in 50 years. The collapse prevention limit-state did not exceed on the IDA curve until the final point where the local tangent reached $20 \%$ of the elastic slope or the drift ratio of $\theta_{\max }=10 \%$, whichever occurred the first in IM terms. The main idea was to place the CP limit-state at a point where the IDA curve would be softening towards the flat line but at sufficiently low values of $\theta_{\text {max }}$ (less than $10 \%$ ) (for ground motions, with a $2 \%$ chance of exceeding in 50 years).
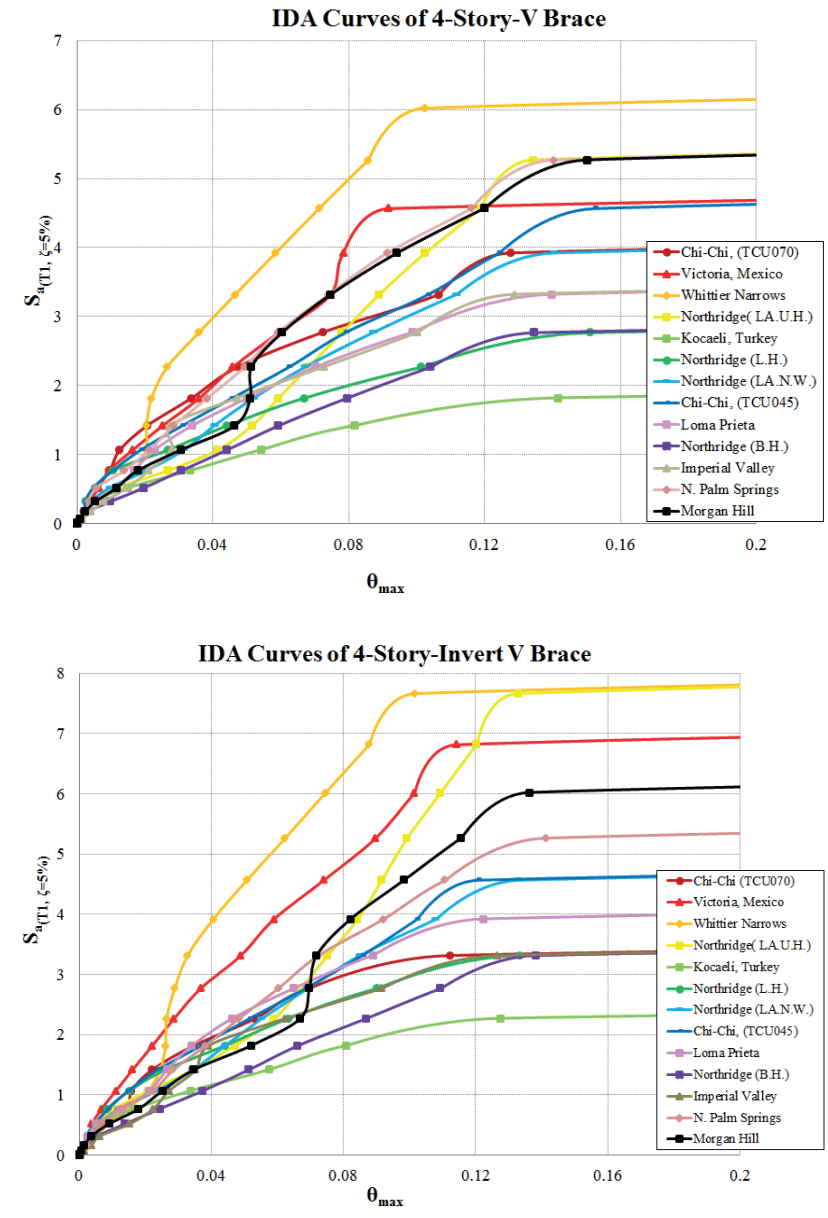

Fig. 4 IDA curves of 4-story BRBfs

The amounts of $S_{a}(16 \%), S_{a}(50 \%)$, and $S_{a}(84 \%)$ were determined in limit states of immediate occupancy and collapse prevention through statistical summarizing (see Fig. 7). The obtained results demonstrated that, by 

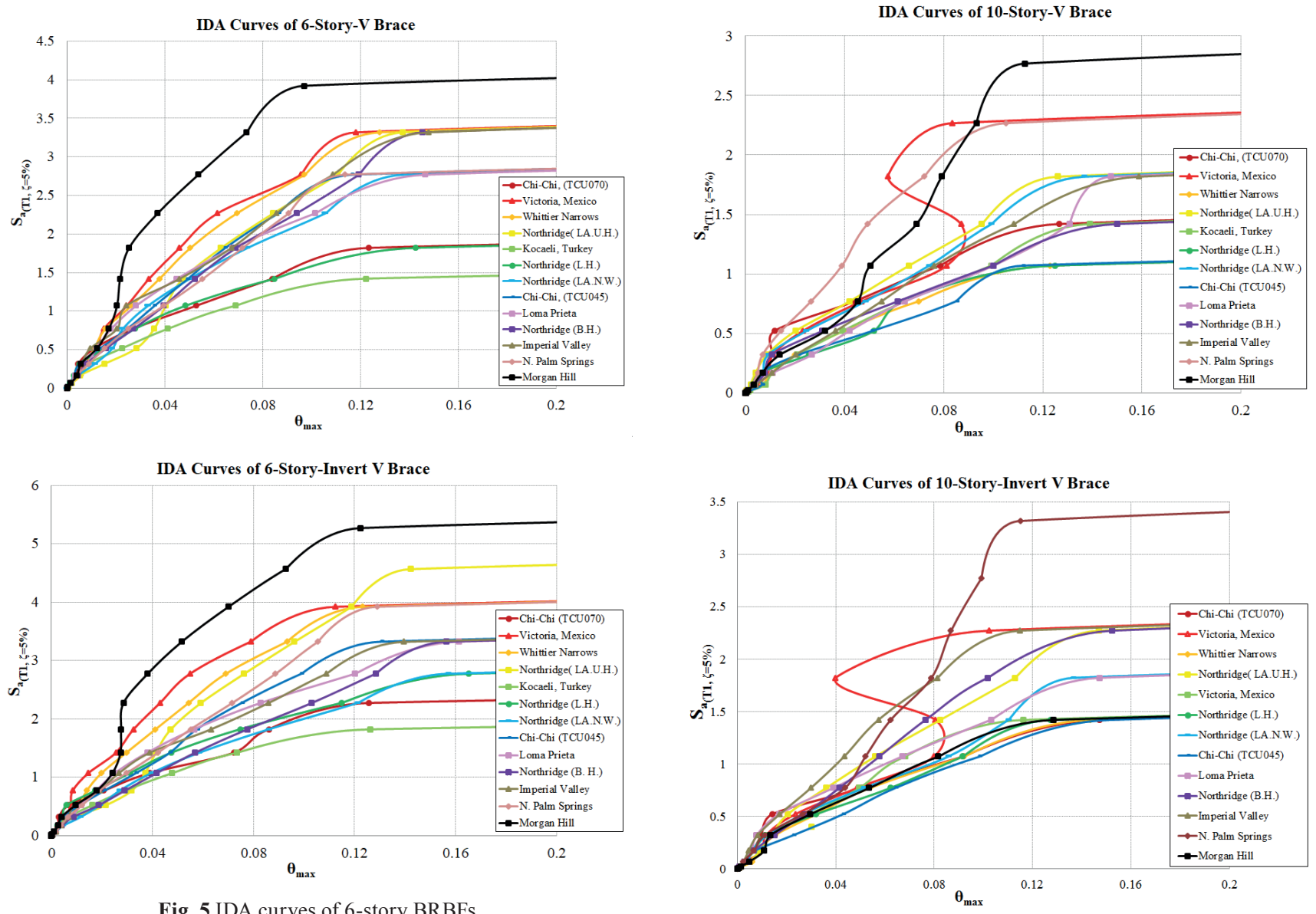

Fig. 5 IDA curves of 6-story BRBFs

increasing height, the amounts of $S_{a}(50 \%)$, defined as "capacity of structure" in probabilistic earthquake engineering, decreased. Furthermore, the structures with inverted Chevron were found to have more capacities.

\subsection{Fragility curves}

Fragility functions of the designed structures were estimated according to Eqs. (9)-(10) and the results of incremental dynamic analyses for both $\mathrm{CP}$ and IO limit states. The obtained fragility curves were compared in two conditions. In the first condition, the effect of changing brace configurations was investigated for the models with the same height, and in the second condition, the effect of increasing structural heights was studied for models with Chevron and Invert-Chevron braces.

Figs. 8 to 10 show the fragility curves of 4-, 6- and 10 -story BRBFs with different bracing configurations.

Also, the fragility curves of 4-, 6- and 10-story Chevron BRBs shown in Figs. 11 and 12.

According to these results, the amount of spectral acceleration $S_{a\left(T_{1} ; 5 \%\right)}$ for 4-story models at the probability of $50 \%$ cumulative failure was estimated to amount to 0.93 and 1.03 for Chevron and inverted Chevron BRBs

at IO limit state, and to 3.06 and 3.71 at CP limit state, respectively. For the 6-story models and at the same failure probability, $S_{a(T ; 5 \%)}$ was 0.66 and 0.8 at the IO limit state and 2.47 and 2.58 at the CP limit state for Chevron and inverted Chevron BRBs, respectively. The amount of 0.39 and 0.43 at the IO limit state and 1.08 and 1.3 at the CP limit state for Chevron and inverted Chevron BRBs, respectively, was estimated for the 10 -story models. These results confirm that the fragility probability of Chevron braces is higher than that of the inverted ones in both limit states (CP and IO levels). This result was obtained for both Chevron and inverted Chevron BRBs.

Eq. (2) was used to estimate the mean relative frequency of exceeding the demand for relative displacement. Based on that, the $k$ and $k_{0}$ seismic hazard parameters were calculated using the analysis of seismic hazard around Tehran at a location with the longitude of 36.37 degrees and latitude of 52.33 degrees. Table 4 shows the $k$ and $k_{0}$ parameters for various natural periods.

By determination of seismic hazard parameters, the mean annual frequency of exceeding the demand range from a relative displacement was estimated in both imme- 

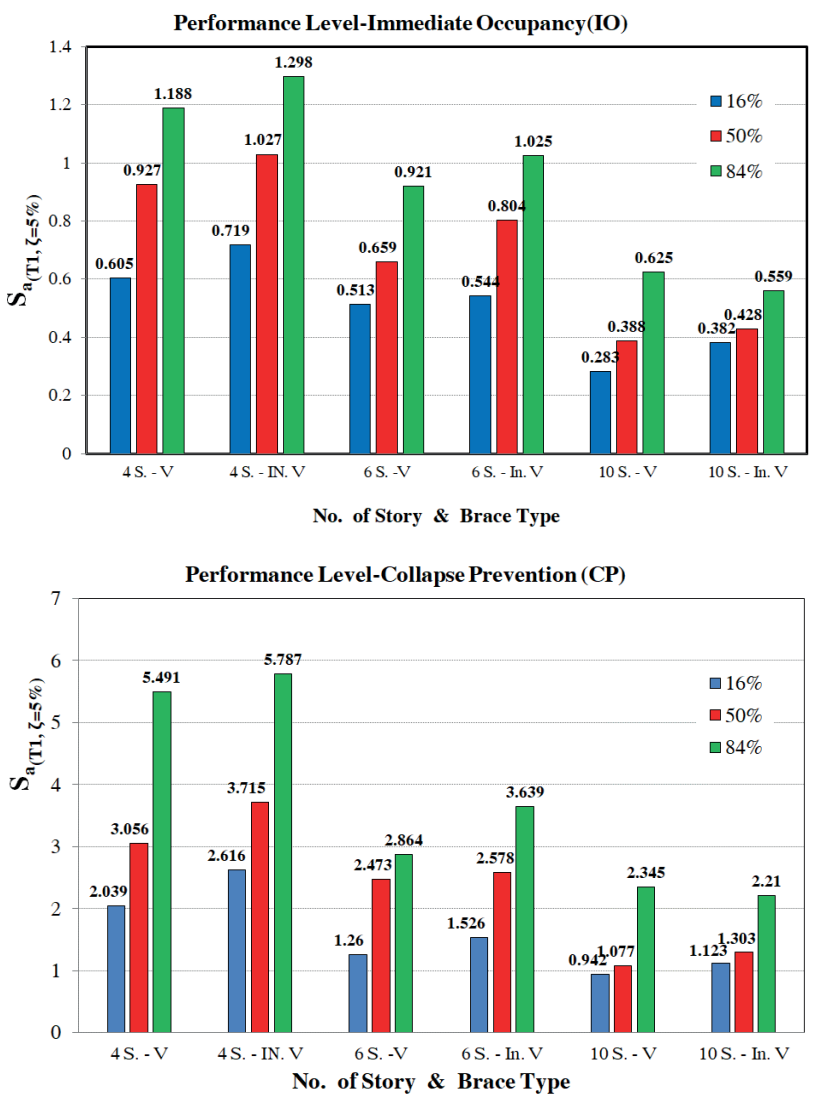

Fig. 7 Summarized Capacities parameter, Sa, at IO \& CP limit states
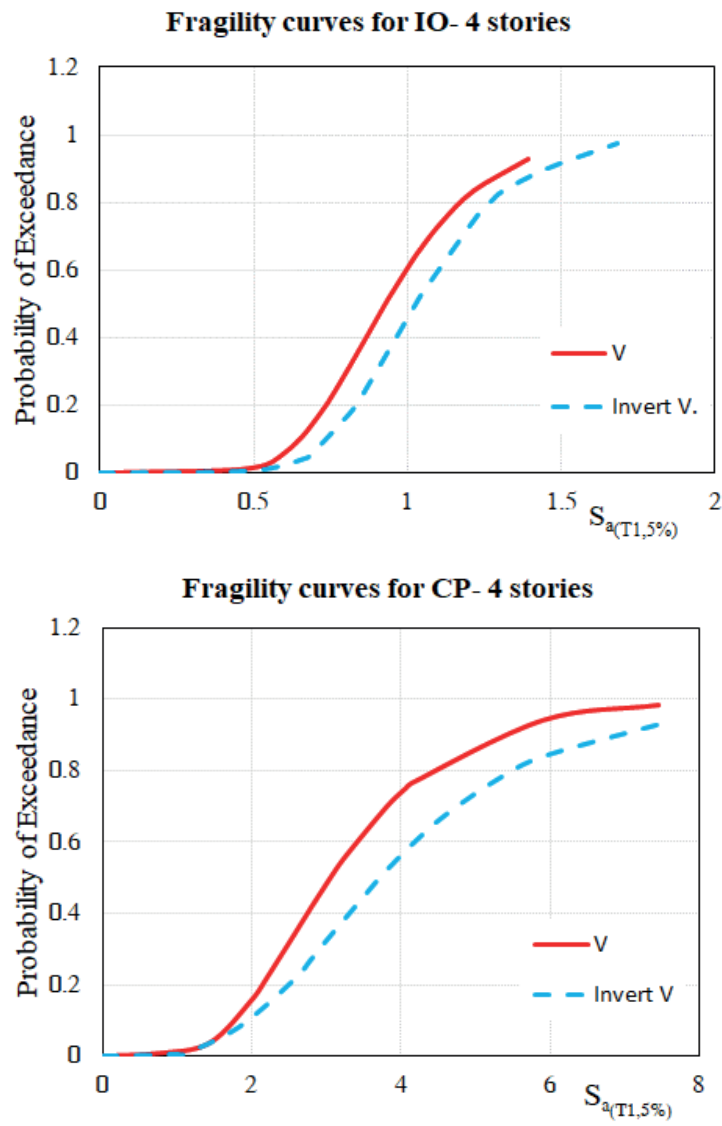

Fig. 8 Fragility curves of 4-story BRBFs at IO and CP limit states
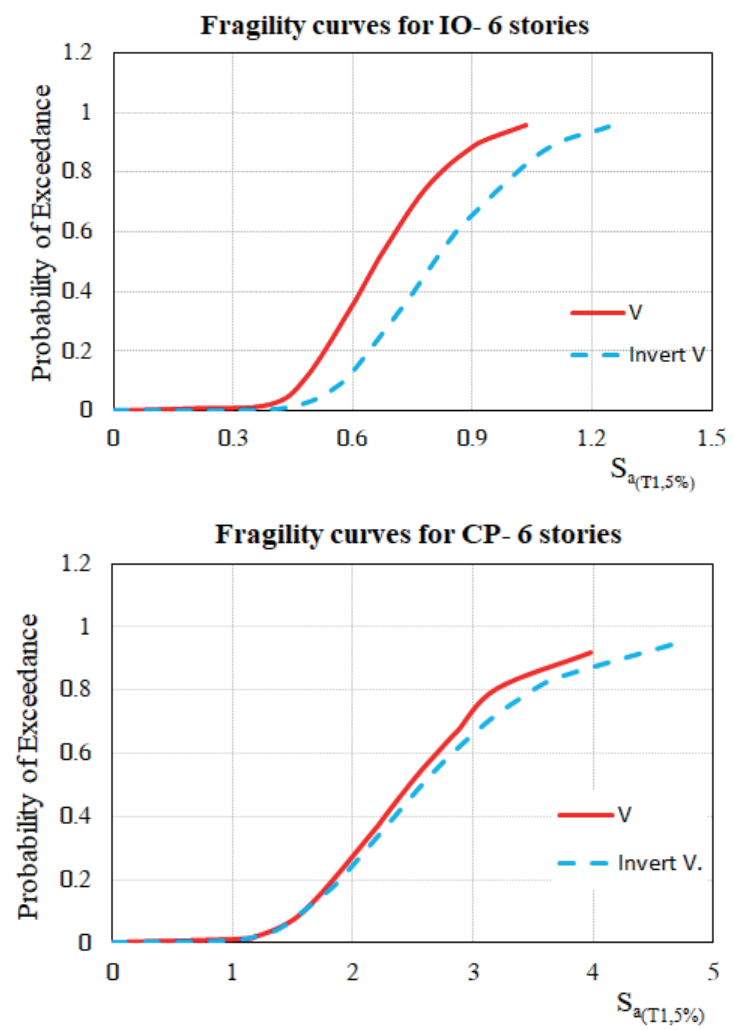

Fig. 9 Fragility curves of 6-story BRBFs at IO and CP limit states
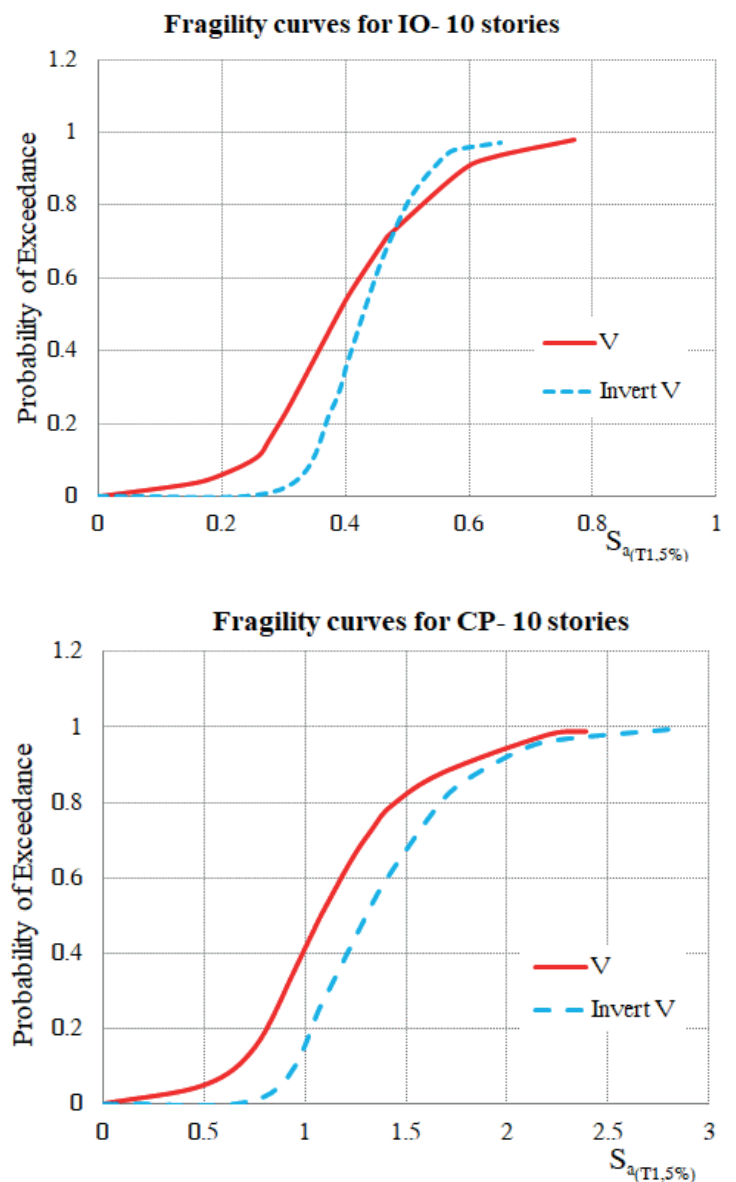

Fig. 10 Fragility curves of 10 -story BRBFs at IO and CP limit states 
Fragility Curves for IO- Chevron V

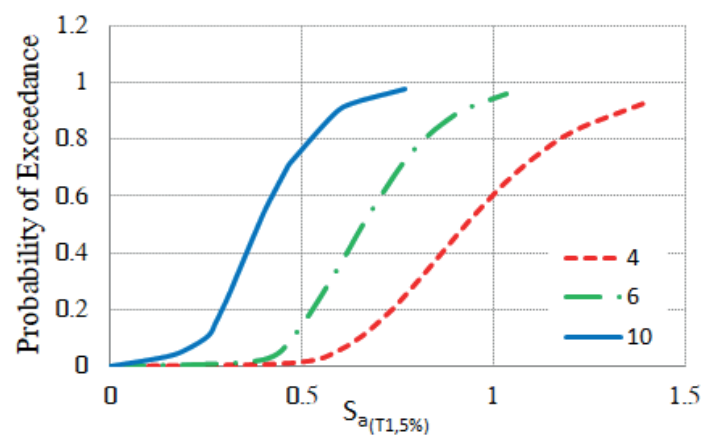

Fragility Curves for CP- Chevron V

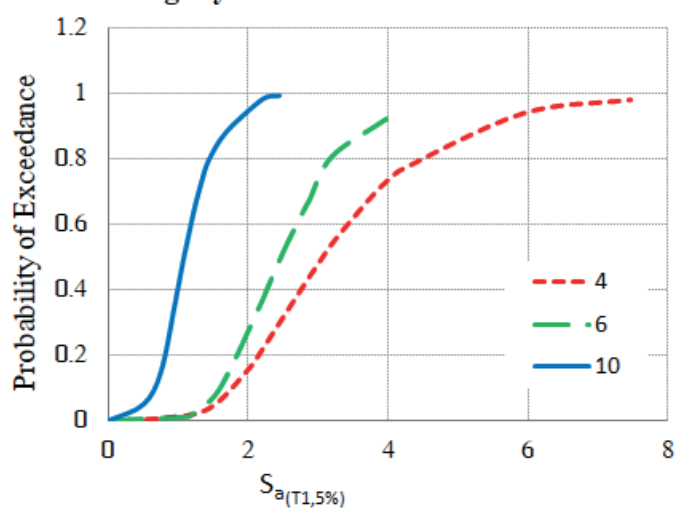

Fig. 11 Fragility curves of chevron BRBs at IO and CP limit states
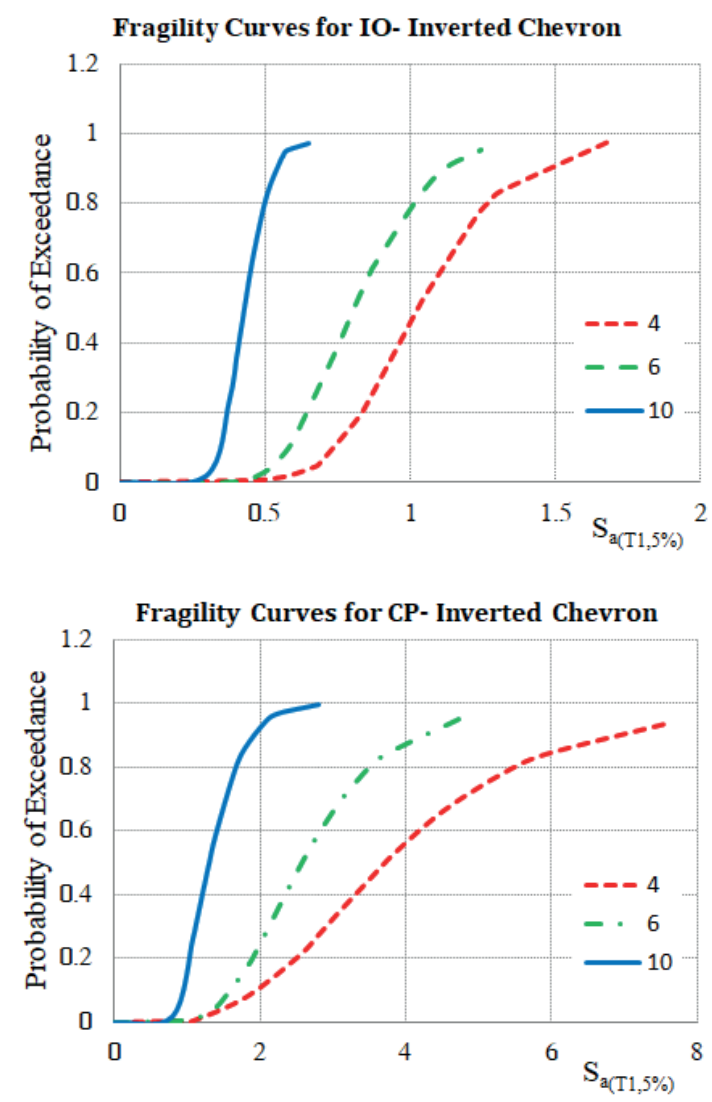

Fig. 12 Fragility curves of invert-chevron BRBs at IO and CP limit states
Table 4 Seismic Hazard Parameters

\begin{tabular}{lcccccc}
\hline$T_{1}(\mathrm{sec})$ & 0.668 & 0.764 & 0.97 & 1.07 & 1.59 & 1.74 \\
\hline$k_{0}$ & 0.0026 & 0.0019 & 0.0010 & 0.00072 & 0.00016 & 0.00012 \\
$k$ & 2.3066 & 2.2173 & 2.292 & 2.2902 & 2.2802 & 2.2468 \\
\hline
\end{tabular}

diate occupancy (IO), and collapse prevention (CP) limit states using the numerical integration. The obtained amounts are reported in Fig. 13. According to Fig. 13, the MAF of exceeding from limit states has decreased by raising the structure height. Furthermore, the Chevron braces demonstrated the best performance in short structures (4- and 6-story), while the inverted Chevron braces showed the finest performance in mid-height structures (10-story). Of note, using this method, the MAF of exceeding limit states was estimated without considering any uncertainties.

The relative displacement hazard curve was evaluated through the repetition of the mentioned process in different amounts of relative displacements. Based on that, the MAF of exceeding all relative displacements was determined for Chevron and inverted Chevron BRBs (Fig. 14). As can be seen in Fig. 14, the relative displacement hazard decreased with an increase in the height of the structures.
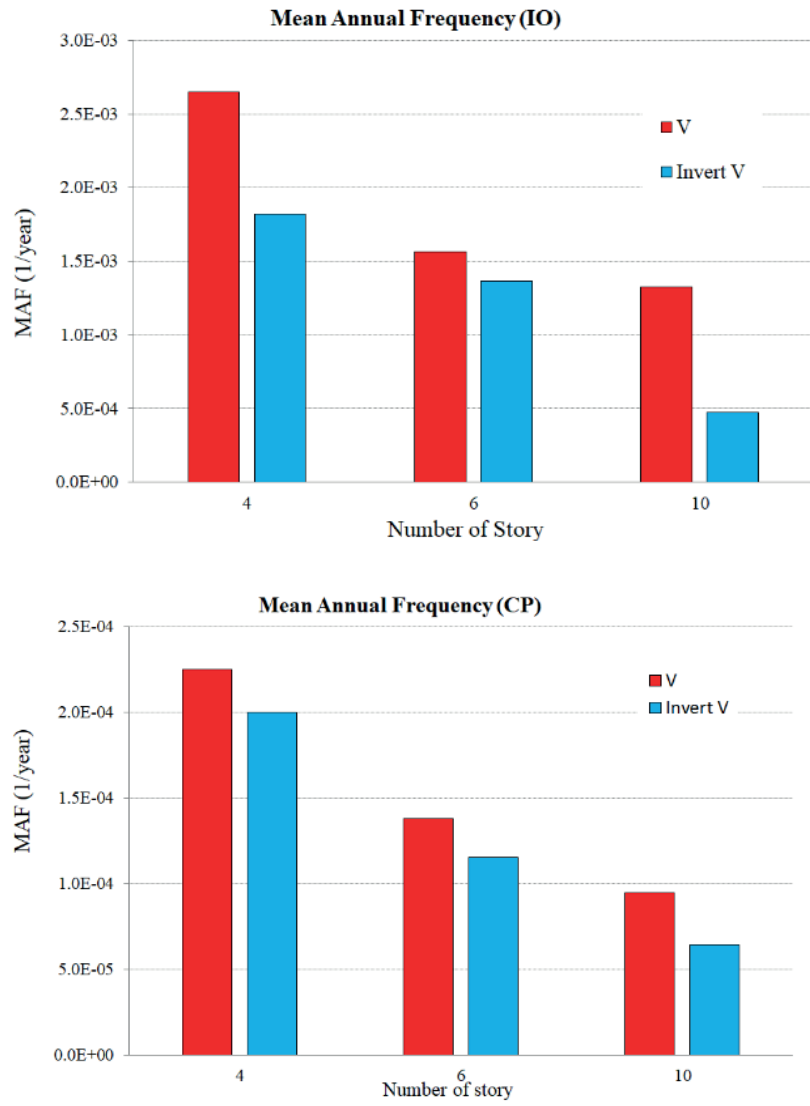

Fig. 13 Mean annual frequency of BRBFs at IO and CP limit states 


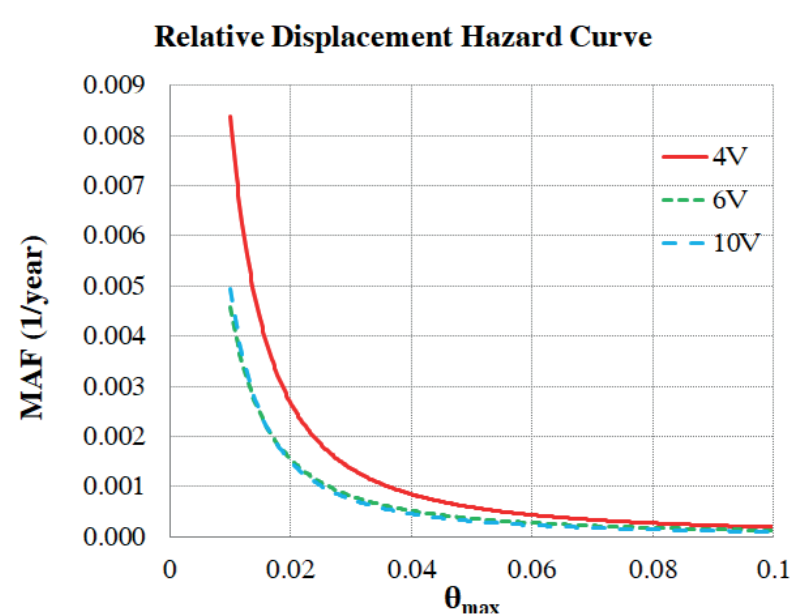

Relative Displacement Hazard Curve

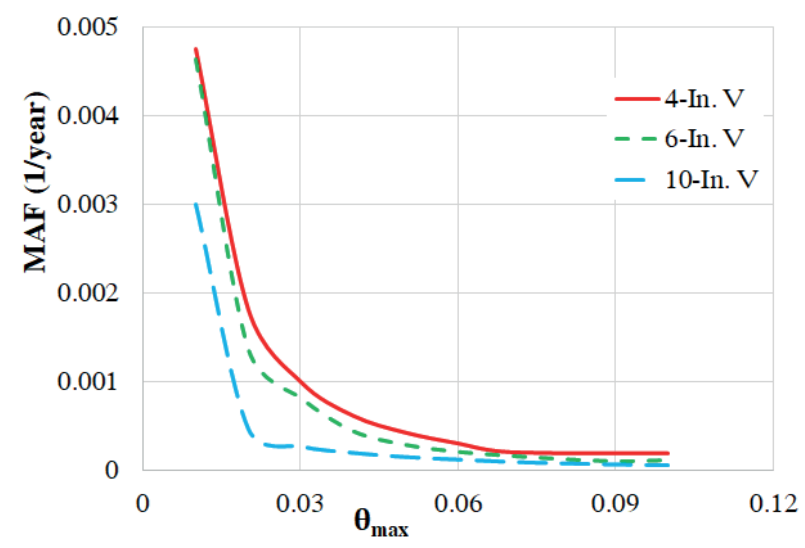

Fig. 14 Relative displacement hazard curves for chevron \& Invert-chevron BRBs

\subsection{Results of the DCFD method}

The main difference between the probabilistic seismic demand analysis method and the demand and capacity factor design (DCFD) method is considering uncertainties in the estimation of seismic parameters. In the present study, the randomness and epistemic uncertainties in the capacity and demand variables were estimated. To this end, the fractional standard deviation of demand, $\beta_{R D}$, was obtained by conducting a regression analysis of $\ln D$ and $\ln S_{a}$ for $16 \%, 50 \%$, and $84 \%$ fractile values. The fractional standard deviation of capacity, $\beta_{R C}$, was estimated by the average $\ln \left(S_{a}^{84^{\text {th }}} / S_{a}^{55^{\text {th }}}\right)$ and $\ln \left(S_{a}^{50^{\text {th }}} / S_{a}^{16^{\text {th }}}\right)$, where $S_{a}^{84^{\text {th }}}, S_{a}^{50^{\text {th }}}$ and $S_{a}^{16^{\text {th }}}$, and denote the spectral acceleration values corresponding to $84 \%, 50 \%$, and $16 \%$ percentiles of the ordered data, respectively. The modeling errors and other approximation involved in this analysis procedure was limited to the statistical uncertainty in the median due to the finite sample size $\left(n_{\text {sample }}=13\right)$ of ground motions. Therefore, $\beta_{U D}$ and $\beta_{U C}$ can be calculated as follows (see Eq. (8)):
$\beta_{U D}=\frac{\beta_{R D}}{\sqrt{n_{s}}}, \quad \beta_{U C}=\frac{\beta_{R C}}{\sqrt{n_{s}}}$

These fractional standard deviations are presented in Tables 5 and 6.

Furthermore, current random uncertainty in the analysis of spectral acceleration and the mean annual frequency of exceeding a limit state corresponding to two studying performance levels were estimated using Eq. (5). In results are reported in Fig. 15. Similarly to the results of the first method, the inverted Chevron buckling braced frames demonstrated better performance and a lower probability to exceed both limit states. Increasing the height of BRBFs leads to a decline in the mean annual frequency of exceeding limit states. A comparison of the results of the DCFD method and those of the relative displacement hazard (i.e., the first method) illustrated that the uncertainty at the probabilistic seismic evaluation led to an increase in the mean annual frequency of exceeding limit states.

\section{Conclusions}

The present study investigated the effects of bracing configurations and building heights at the seismic performance of buckling restrained braced frames by estimating the mean annual frequency of exceeding limit states.

Table 5 Summarized randomness and uncertainty in parameters at IO limit-state

\begin{tabular}{lccccc}
\hline $\begin{array}{l}\text { No. } \\
\text { Story }\end{array}$ & $\begin{array}{l}\text { Brace } \\
\text { Shape }\end{array}$ & $\left(\beta_{R D}\right)$ & $\left(\beta_{U D}\right)$ & $\left(\beta_{R C}\right)$ & $\left(\beta_{U C}\right)$ \\
\hline \multirow{2}{*}{4} & V & 0.246 & 0.068 & 0.337 & 0.094 \\
& IN. V & 0.237 & 0.066 & 0.295 & 0.082 \\
6 & V & 0.217 & 0.060 & 0.293 & 0.081 \\
& IN. V & 0.244 & 0.068 & 0.317 & 0.088 \\
10 & V & 0.266 & 0.074 & 0.396 & 0.110 \\
& IN. V & 0.206 & 0.057 & 0.190 & 0.053 \\
\hline
\end{tabular}

Table 6 Summarized randomness and uncertainty in parameters at CP limit-state

\begin{tabular}{lccccc}
\hline $\begin{array}{l}\text { No. } \\
\text { Story }\end{array}$ & $\begin{array}{l}\text { Brace } \\
\text { Shape }\end{array}$ & $\left(\beta_{R D}\right)$ & $\left(\beta_{U D}\right)$ & $\left(\beta_{R C}\right)$ & $\left(\beta_{U C}\right)$ \\
\hline \multirow{2}{*}{4} & $\mathrm{~V}$ & 0.300 & 0.083 & 0.495 & 0.137 \\
& IN. V & 0.252 & 0.070 & 0.397 & 0.110 \\
6 & $\mathrm{~V}$ & 0.243 & 0.067 & 0.411 & 0.114 \\
& IN. V & 0.258 & 0.072 & 0.435 & 0.121 \\
10 & $\mathrm{~V}$ & 0.278 & 0.077 & 0.456 & 0.126 \\
& $\mathrm{IN} . \mathrm{V}$ & 0.229 & 0.063 & 0.338 & 0.094 \\
\hline
\end{tabular}



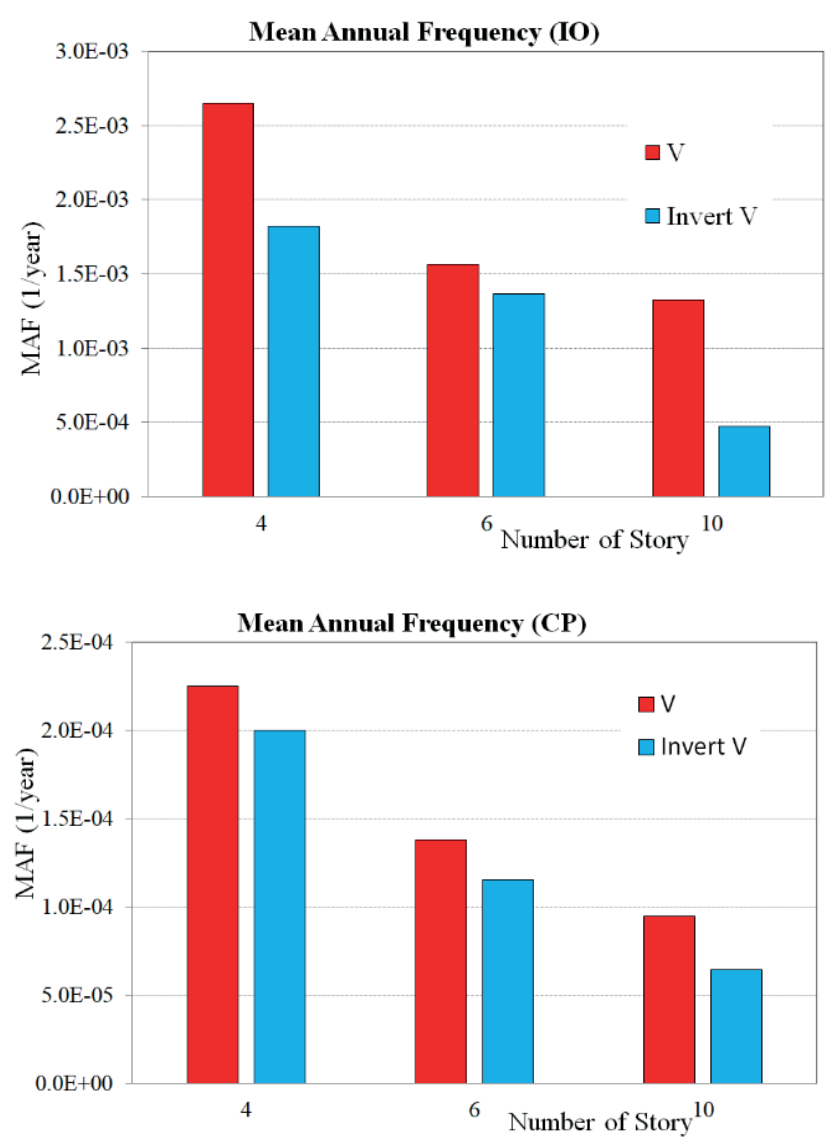

Fig. 15 Mean Annual frequency of exceeding limit states at CP and IO levels

To this end, two methods were applied: the probabilistic seismic demand analysis (fragility curves) method and a solution based on the displacement in demand and capacity factor design method. The main difference between these two methods is that only the second method considers the randomness and epistemic uncertainties. A complete 2D model of 4-, 6-, 10-story BRBFs with two bracing configurations (Chevron and invert-Chevron) was developed using the OpenSees software. The demand and capacity of each model at two limit states (immediate occupancy and collapse prevention) were extracted using the incremental dynamic analysis method and ten ground motion records. Based on our results, the following conclusions can be drawn.

\section{References}

[1] Merczel, D. B., Aribert, J.-M., Somja, H., Hjiaj, M. "Plastic analysis-based seismic design method to control the weak storey behaviour of concentrically braced steel frames", Journal of Constructional Steel Research, 125, pp. 142-163, 2016.

https://doi.org/10.1016/j.jcsr.2016.05.008
The capacity of BRBFs with inverted Chevron braces, amounts of $S_{a}(50 \%)$, was more than that of the structures with Chevron braces. Besides, in structures with both bracing configurations, the capacity of structures decreased with an increase in the number of stories.

The fragility probability has increased in the models with both bracing configurations by increasing the height of the model. This result was substantiated for both immediate occupancy and collapse prevention limit states without considering the seismic hazard analysis. Therefore, it can be concluded that an earthquake has a more destructive effect on tall structures.

In the buildings of the same height, the fragility probability of BRBFs with Chevron braces was more than that of BRBFs with inverted Chevron braces; this issue could be attributed to the initial elastic stiffness and the amount of ductility. The mean difference of spectral acceleration, $S_{a(T 1 ; 5 \%}$, in the probability of $50 \%$ cumulative failure for these two bracing configurations was estimated to amount to $12.5 \%$, and $13 \%$ at the IO and CP limit states, respectively.

The mean annual frequency of exceeding the IO and CP limit states decreased with an increase of the height of structures, for both of bracing configurations. In other words, the return periods of exceeding a limit state increased with an increase in the height of the structures. Both methods substantiated these results.

The seismic demand hazard decreased in both brace configurations with an increase in the height of structures. Both methods converged in yielding this result.

Randomness and epistemic uncertainties in the estimation of capacity and demand variables led to an increase in the probability of exceeding a limit state. Therefore, it can be concluded that these parameters have a considerable effect on the seismic evaluation of any structure.

\section{Acknowledgment}

This work was supported by a 2018 Incheon National University (INU) Research Grant. The authors gratefully acknowledge these supports.

[2] Merczel, D. B., Aribert, J.-M., Somja, H., Hjiaj, M., Lógó, J. "A method to avoid weak storey mechanisms in concentrically braced frames", presented at 8th International Conference on Behavior of Steel Structures in Seismic Areas, Shanghai, China, July, 1-3, 2015. 
[3] Merczel, D. B., Somja, H., Aribert, J.-M., Hjiaj, M., Lógó, J. "Plasticity-based method to avoid weak storey behaviour of concentrically braced frames", presented at 7th European Conference on Steel and Composite Structures, Eurosteel 2014, Naples, Italy, Sep, 10-12, 2014.

[4] Merczel, D. B., Somja, H., Aribert, J.-M., Lógó, J. "On the behaviour of concentrically braced frames subjected to seismic loading", Periodica Polytechnica Civil Engineering, 57(2), pp. 113-122, 2013.

https://doi.org/10.3311/PPci.7167

[5] Özkılıç, Y. O., Bozkurt, M. B., Topkaya, C. "Evaluation of seismic response factors for BRBFs using FEMA P695 methodology", Journal of Constructional Steel Research, 151, pp. 41-57, 2018. https://doi.org/10.1016/j.jesr.2018.09.015

[6] Beiraghi, H. "Energy demands in reinforced concrete wall piers coupled by buckling restrained braces subjected to near-fault earthquake", Steel and Composite Structures, 27(6), pp. 703-716, 2018. https://doi.org/10.12989/scs.2018.27.6.703

[7] Hadianfard, M. A., Eskandari, F., Javidsharifi, B. "The effects of beam-column connections on behavior of buckling-restrained braced frames", Steel and Composite Structures, 28(3), pp. 309318, 2018.

https://doi.org/10.12989/scs.2018.28.3.309

[8] Mehdipanah, A., Mirghaderi, S. R., Razavi Tabatabaei, S. A. "Seismic performance of stiffness-based designed buckling-restrained braced frame and special moment-resisting frame dual systems", Structure and Infrastructure Engineering, 12(8), pp. 918-935, 2016.

https://doi.org/10.1080/15732479.2015.1071854

[9] Feng, Y., Wu, J., Meng, S. "Elastic Displacement Spectrum-Based Design Approach for Buckling-Restrained Braced Frames", Journal of Earthquake Engineering, 20(6), pp. 841-860, 2016. https://doi.org/10.1080/13632469.2015.1104762

[10] Black, C., Makris, N., Aiken, I. "Component Testing, Stability Analysis and Characterizationof Buckling-Restrained Unbonded BracesTM", Pacific Earthquake Engineering Research Center, University of California, Berkeley, CA, USA, Rep. PEER 2002/8, 2002. [online] Available at: https://peer.berkeley.edu/sites/default/ files/0208_c._black_n._makris_i._aiken.pdf

[11] Mahmoudi, M., Zaree, M. "Determination the Response Modification Factors of Buckling Restrained Braced Frames", Procedia Engineering, 54, pp. 222-231, 2013. https://doi.org/10.1016/j.proeng.2013.03.020

[12] Talebi, E., Tahir, M. M., Zahmatkesh, F., Kueh, A. B. H. " Comparative study on the behaviour of Buckling Restrained Braced frames at fire", Journal of Constructional Steel Research, 102, pp. 1-12, 2014.

https://doi.org/10.1016/j.jcsr.2014.06.003

[13] Asgarian, B., Shokrgozar, H. R. "BRBF response modification factor", Journal of Constructional Steel Research, 65(2), pp. 290298, 2009.

https://doi.org/10.1016/j.jcsr.2008.08.002

[14] Lin, K.-C., Lin, C.-C. J., Chen, J.-Y., Chang, H.-Y. "Seismic reliability of steel framed buildings", Structural Safety, 32(3), pp. 174-182, 2010.

https://doi.org/10.1016/j.strusafe.2009.11.001
[15] Güneyisi, E. M. "Seismic reliability of steel moment resisting framed buildings retrofitted with buckling restrained braces", Earthquake Engineering and Structural Dynamics, 41(5), pp. 853874, 2012. https://doi.org/10.1002/eqe.1161

[16] Ariyaratana, C., Fahnestock, L. A. "Evaluation of buckling-restrained braced frame seismic performance considering reserve strength", Engineering Structures, 33(1), pp. 77-89, 2011. https://doi.org/10.1016/j.engstruct.2010.09.020

[17] Maley, T. J., Sullivan, T. J., Della Corte, G. "Development of a Displacement-Based Design Method for Steel Dual Systems With Buckling-Restrained Braces and Moment-Resisting Frames", Journal of Earthquake Engineering, 14(Sup1), pp. 106-140, 2010. https://doi.org/10.1080/13632461003651687

[18] Sutcu, F., Takeuchi, T., Matsui, R. "Seismic retrofit design method for RC buildings using buckling-restrained braces and steel frames", Journal of Constructional Steel Research, 101, pp. 304-313, 2014. https://doi.org/10.1016/j.jcsr.2014.05.023

[19] Atlayan, O., Charney, F. A. "Hybrid buckling-restrained braced frames", Journal of Constructional Steel Research, 96, pp. 95-105, 2014. https://doi.org/10.1016/j.jcsr.2014.01.001

[20] Hu, J.-W., Choi, E. "Seismic design, nonlinear analysis, and performance evaluation of recentering buckling-restrained braced frames (BRBFs)", International Journal of Steel Structures, 14(4), pp. 683-695, 2014. https://doi.org/10.1007/s13296-014-1201-3

[21] Jiang, Z., Guo, Y., Zhang, B., Zhang, X. "Influence of design parameters of buckling-restrained brace on its performance", Journal of Constructional Steel Research, 105, pp. 139-150, 2015. https://doi.org/10.1016/j.jcsr.2014.10.024

[22] Zeynali, K., Monir, H. S., Mirzai, N. M., Hu, J. W. "Experimental and numerical investigation of lead-rubber dampers in chevron concentrically braced frames", Archives of Civil and Mechanical Engineering, 18(1), pp. 162-178, 2018. https://doi.org/10.1016/j.acme.2017.06.004

[23] Khan, R. A., Datta, T. K. "Seismic risk analysis of harp type cable stayed bridges", Ingegneria Sismica, 27(4), pp. 5-16, 2010. [online] Available at: http://ingegneriasismica.org/analisi-delrischio-sismico-di-ponti-strallati/

[24] Khan, R. A., Datta, T. K. "Effect of support flexibility and soil- structure interaction on seismic risk analysis of harp type cable stayed bridges", Ingegneria Sismica, 31(2), pp. 32-46, 2014. [online] Available at: http://ingegneriasismica.org/effect-of-support-flexibility-and-soil-structure-interaction-on-seismic-risk-analysis-of-harptype-cable-stayed-bridges-2/

[25] Mansouri, I., Amiri, G. G., Hu, J. W., Khoshkalam, M., Soori, S., Shahbazi, S. "Seismic Fragility Estimates of LRB Base Isolated Frames Using Performance-Based Design", Shock and Vibration, Article ID: 5184790, 2017. https://doi.org/10.1155/2017/5184790

[26] Isık, E., Kutanis, M., Bal, İ. W. "Displacement of the Buildings According to Site-Specific Earthquake Spectra", Periodica Polytechnica Civil Engineering, 60(1), pp. 37-43, 2016. https://doi.org/10.3311/PPci.7661 
[27] Jalayer, F., Cornell, C. A. "A Technical Framework for ProbabilityBased Demand and Capacity Factor Design (DCFD) Seismic Formats", Pacific Earthquake Engineering Research Center, University of California, Berkeley, CA, USA, Rep. PEER 2003/08, 2003. [online] Available at: https://peer.berkeley.edu/sites/default/ files/0308_f._jalayer_c._allin_cornell.pdf

[28] Vamvatsikos, D., Cornell, C. A. "Incremental dynamic analysis", Earthquake Engineering and Structural Dynamics, 31(3), pp. 491$514,2002$. https://doi.org/10.1002/eqe.141

[29] Luco, N., Cornell, C. A. "Seismic drift demands for two SMRF structures with brittle connections", In: Proceedings of the Structural Engineers World Congress, 1998, San Francisco, CA, USA, 1998, Paper T158-3.

[30] Ibarra, L. F., Medina, R. A., Krawinkler, H. "Hysteretic models that incorporate strength and stiffness deterioration", Earthquake Engineering \& Structural Dynamics, 34(12), pp. 1489-1511, 2005. https://doi.org/10.1002/eqe.495

[31] Baker, J. W. "Efficient Analytical Fragility Function Fitting Using Dynamic Structural Analysis", Earthquake Spectra, 31(1), pp. 579$599,2015$.

https://oi.org/10.1193/021113eqs025m

[32] ASCE "ASCE7-10 Minimum Design Loads for Buildings and Other Structures", American Society of Civil Engineers, Reston, VA, USA, 2010. https://doi.org/10.1061/9780784412916

[33] Mazzoni, S., McKenna, F., Fenves, G. L. "OpenSees Manual" Pacific Earthquake Engineering Research Center, University of California, Berkeley, CA, USA, 2013. [online] Available at: https://opensees. berkeley.edu/OpenSees/manuals/comparisonManual/1417.htm
[34] Ahmadi, M., Naderpour, H., Kheyroddin, A., Gandomi, A. H. "Seismic Failure Probability and Vulnerability Assessment of SteelConcrete Composite Structures", Periodica Polytechnica Civil Engineering, 61(4), pp. 939-950, 2017.

https://doi.org/10.3311/PPci.10548

[35] Farzampour, A., Mansouri, I., Dehghani, H. "Incremental Dynamic Analysis for Estimating Seismic Performance of Multi-Story Buildings with Butterfly-Shaped Structural Dampers", Buildings, 9(4), Article number: 78, 2019.

https://doi.org/10.3390/buildings9040078

[36] Mirzai, N. M., Attarnejad, R., Hu, J. W. "Enhancing the seismic performance of EBFs with vertical shear link using a new self-centering damper", Ingegneria Sismica, 35(4), pp. 57-76, 2018.

[37] De Matteis, G., Brando, G., Caldoso, F., D'Agostino, F. "Seismic performance of dual steel frames with dissipative metal shear panels", Ingegneria Sismica, 35(2), pp. 124-141, 2018. [online] Available at: http://ingegneriasismica.org/seismic-performance-ofdual-steel-frames-with-dissipative-metal-shear-panels/

[38] Giordano, V., Chisari, C., Rizzano, G., Latour, M. "Prediction of seismic response of moment resistant steel frames using different hysteretic models for dissipative zones", Ingegneria Sismica, 34(4), pp. 42-56, 2017. [online] Available at: http://ingegneriasismica.org/prediction-of-seismic-response-of-moment-resistant-steel-frames-using-different-hysteretic-models-for-dissipative-zones/

[39] Soltangharaei, V., Razi, M., Gerami, M. "Comparative Evaluation of Behavior Factor of SMRF Structures for Near and Far Fault Ground Motions", Periodica Polytechnica Civil Engineering, 60(1), pp. 75-82, 2016.

https://doi.org/10.3311/PPci.7625 